\title{
Rhythmic Repair of Morphological Accent Assigned Outside of a Metrical Window
}

\author{
Nicholas Rolle \\ University of California, Berkeley
}

\section{Introduction}

This paper studies the interaction of two phonological phenomena. The first is phonological accent which is lexically pre-specified on a specific morpheme (lexical accent) or assigned to a target in specific morphological contexts (morphological accent) (Alderete 2001, among other theoretical treatments). Accent here is defined as an abstract mark on a specific syllable (i.e. a diacritic) and is therefore a phonological notion distinct from phonetic prominence/stress. In this paper, I only look at data involving morphological accent, but the core parts of this analysis can be extend to lexical accent systems as well. The second phenomenon is a metrical window, often referred to as a stress window within the literature (Kager 2012). A metrical window is defined as a designated number of syllables/moras at the edge of a domain within which primary prominence (i.e. stress) is restricted. For example, a right-edge 3 syllable metrical window refers to a prosodic system where primary prominence can only appear on one of the final three syllables of the relevant domain, most commonly the phonological word.

When phonological accent falls on a syllable within the designated metrical window, accent aligns with primary prominence. For example, Standard Literary Macedonian has a lexical accent system involving lexically-prespecified accent with certain words. In example (1)a below, lexical accent appears on the penultimate syllable. In this example and throughout, morphological accent is indicated by underlining the accented syllable and marking it with an acute accent. When this word is in isolation, accent falls within a designated right-edge 3 syllable window and therefore aligns with primary prominence, shown in (1)b. In this example and throughout, primary prominence is indicated by boldening and italicizing the syllable and marking it with an acute accent. In contrast, in (1)c the root appears with a definite plural suffix -ite, which consequently pushes the accent outside of the metrical window where it appears on the fourth-to-last syllable. The result is that accent can no longer align with primary prominence, and prominence instead reverts to a default position, in this language the antepenultimate.

(1) Standard Literary Macedonian (Kager 2012:1457)

a. Lexical accent on penult

/ kon.zu.má.tor / 'consumer'

b. Lexical accent aligns with primary prominence within metrical window

[ kon.zu.má.tor ]

c. Lexical accent outside window - Primary prominence reverting to default position

[ kon.zu.ma tó.r-i.te] ] 'the consumers' (*[ kon.zu.má to.r-i.te ])

I refer to cases where primary prominence occurs on a default position when accent is outside the metrical window as default repair, which Kager (2012) shows to be a cross-linguistically widespread repair. ${ }^{1}$

\footnotetext{
* Primary thanks go to Marine Vuillermet, the main researcher on Ese'eja and frequent collaborator, who collected the entirety of this data. Our joint gratitude goes to the people of these communities who worked on this project, especially Calixto Callaú Casirno† (aka Kanono). This work was presented at the 2016 Annual Meeting on Phonology and 2017 LSA. Thanks to Anthony Yates and Ryan Bennett in particular for their thoughts, and to Berkeley colleagues Sharon Inkelas, Larry Hyman, Florian Lionnet, Zach O’Hagan, Lev Michael, Kelsey Neely, and Emily Clem.

${ }^{1}$ I use the term 'repair' here to designate a language-specific response to the problem faced when accent cannot align with primary prominence, and admit that referring to a phonological output as 'repaired' is strictly speaking inaccurate.
} 
In contrast, I propose a novel type of repair which I term rhythmic repair. Under this type, when morphological accent is assigned outside of a metrical window, primary prominence falls on a position which is rhythmically dependent on the window-external accent, e.g. being uniformly 2 syllables away. The difference between these types is schematized in Table 1 below with a left-edge 3 syllable metrical window. With default repair, the position of primary prominence will uniformly be on the default regardless of where the window-external accent falls; different grammars place the default on the first, second, or third syllable. With rhythmic repair, however, the position of primarily prominence will be on a rhythmically dependent position, e.g. when accent falls on the $4^{\text {th }} \sigma$, prominence is on the $2^{\text {nd }} \sigma$, but when accent is on the $5^{\text {th }} \sigma$, prominence will be on the $1^{\text {st }}$ or $3^{\text {rd }} \sigma$ depending on the grammar's parameters. Crucially, the position of prominence is not uniform, and shows dependence on the external accent.

Table 1: Window-external accent repairs

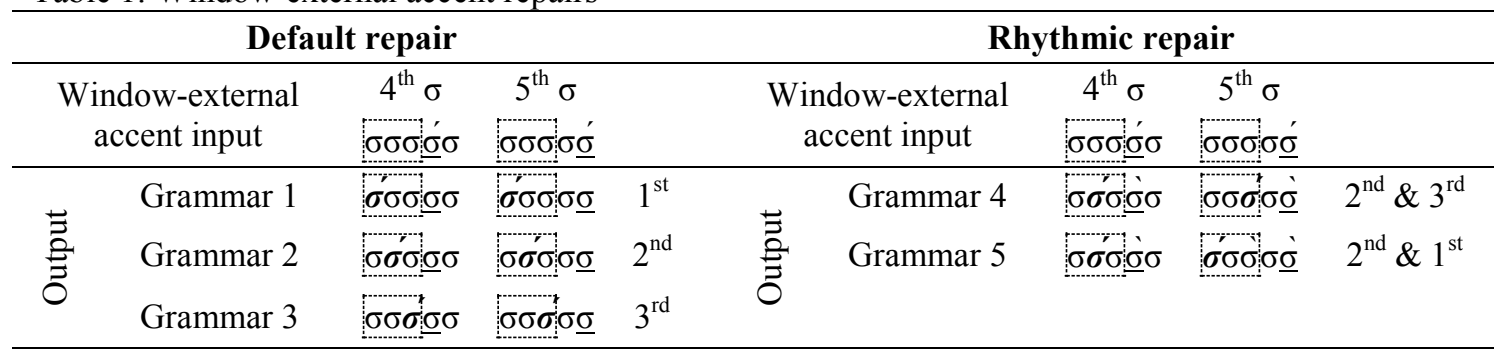

The main claim of this paper is that the language Ese'eja provides empirical support for rhythmic repair in both verbal and nominal domains. In both domains, this language demonstrates a rare left-edge 3-syllable

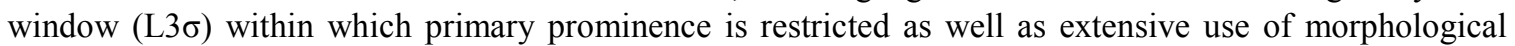
accent. I demonstrate that the position and behavior of the morphological accent depends on the specific morphological sponsor, for example some tense/mood suffixes trigger the creation of iambs while others trigger trochees. Despite this diversity, all cases show evidence for rhythmic repair, and demonstrate how rhythmic effects play a role in the alignment of accent and primary prominence.

In the discussion section, I provide arguments against viewing the Ese'eja data as a complex type of default repair involving multiple morphosyntactically conditioned defaults. Further, I formalize the differences between default and rhythmic repair, following Kager's (2012) view of metrical windows as decomposable into Optimality Theory constraints. I show that default repair involves highly ranked wordto-foot alignment constraints (e.g. ALIGN-WD-L) above lower ranked FAITH-ACCENT and PARSE-SYL. In contrast, rhythmic repair involves splitting FAITH-ACCENT into ACCENT-TO-PROMINENCE (ACC-PROM) and ACCENT-TO-PRIMARYPRominenCE (ACC-PRIMPROM), and ranking PARSE-SYl, ACC-PROM, and an EDGEMOST constraint above ACC-PRIMPROM and word-to-foot alignment constraints.

\section{Case study: Rhythmic repair in Ese'eja}

2.1 Brief background on Ese'eja Ese'eja is a Takanan language spoken in Peru and Bolivia by approximately 1,500 people [ISO 639-3: ese]. Relevant to this analysis, it has maximally (C)V syllables with no consonant clusters or codas, and 4 vowel contrasts /i e a o/ and 3 diphthongs /ia io oe/ <ya yo we $>$. Adjacent vowels are treated as separate vowels as evidenced by accent shifts, e.g. mei /mei/ [méj] 'stone' becomes $/ \mathrm{mei}=\mathrm{a} /$ [meía] 'stone=INS' when modified, not $*$ [méja]. The language is polysynthetic with a large set of affixes and clitics on major parts of speech, and default Ergative-Absolutive-Verb word order. ${ }^{2}$

Ese'eja prosody has been studied previously in Key \& Wyma (1964), Vuillermet (2012), Rolle (2013), and Rolle \& Vuillermet (in press). The latter three sources clearly establish that Ese'eja has a typologically

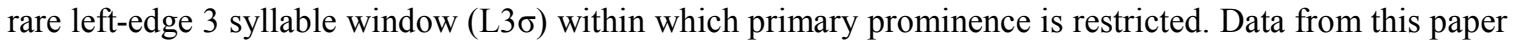
is on the Madidi dialect collected by Marine Vuillermet, and the extensive description of the prosodic system in Vuillermet's (2012) grammar. Both nominal and verbal affixes/clitics involve systematic

${ }^{2}$ Spelling conventions for the Ese'eja data used here which do not comply with the IPA are $\left.\left./ \mathrm{t} f /<\mathrm{ch}\right\rangle, / \mathrm{P} /\left\langle\mathbf{}^{\prime}\right\rangle, / \mathrm{b} /<\mathrm{b}\right\rangle$, $|\mathrm{d} / /<\mathrm{d}>, / \mathrm{J} /<\mathrm{sh}>,| \chi \mid<\mathrm{j}>, / \mathrm{n} /<\tilde{\mathrm{n}}>$, and $/ \mathrm{j} /<\mathrm{y}>$. For the sake of simplicity, I write the orthographic spelling within analytic representations // and [ ] in many places in this paper. 
morphologically conditioned accent changes which shift the position of accent to specific designated positions. The cases I concentrate on demonstrate the role of rhythmic effects in the determination of primary prominence, and specifically, those where morphological accent is assigned to a position outside the $\mathrm{L} 3 \sigma$ window.

2.2 Rhythmic effects in the L3 $\sigma$ window with nouns Nouns in Ese'eja can appear in isolation and may be 1 to 4 syllables in length, although only one 4 syllable monomorphemic noun has been found (iñawewa 'dog'). With bare nouns, primary prominence is found on the penultimate syllable (ultima with $1 \sigma)$ respecting the $\mathrm{L} 3 \sigma$ metrical window, shown in (2) (a small class of nouns deviates from these patterns).

\begin{tabular}{|c|c|c|c|}
\hline $\begin{array}{l}\text { (2) } 1-\sigma \\
k \boldsymbol{e}^{\prime} \text { 'field, }\end{array}$ & $\begin{array}{l}2-\sigma \\
\text { dá ki 'clothes' }\end{array}$ & $\begin{array}{l}3-\sigma \\
\text { ba wícho 'rat' }\end{array}$ & $\begin{array}{l}\text { 4- } \sigma \\
\text { i.ña.wé.wa 'dog' }\end{array}$ \\
\hline
\end{tabular}

I analyze these data as the result of a binary iamb interacting with anti-alignment constraints at both word edges, resulting in [i.(ña.wé).wa]. Within this analysis, a higher ranked right-edge anti-alignment constraint would result in forms [(dá).ki] and [(ba.wí).cho], and a constraint enforcing at least one foot in a word would result in $[(\boldsymbol{k} \boldsymbol{e})]$. This is shown in analysis 1 within Table 2.

Table 2: Default position of primary prominence in nouns

\begin{tabular}{|c|c|c|c|}
\hline Surface position & Analysis 1 (adopted here) & Alt. analysis 2 & Alt. analysis 3 \\
\hline $1 \sigma \quad[\boldsymbol{k} \boldsymbol{e}]$ & $(\boldsymbol{k e ́})$ & $(k e ́)$ & $(k e ́)$ \\
\hline [dá.ki ] & (dá).ki & (dá.ki) & (dá).ki \\
\hline [ ba.wí.cho ] & (ba.wí).cho & ba.(wí.cho) & (ba.wí).cho \\
\hline $4 \sigma \quad[$ i.ña.wé.wa ] & i.(ña.wé).wa & i.ña.(wé.wa) & (i. [ña.wé]).wa \\
\hline \multirow{2}{*}{$\begin{array}{l}\text { Foot type } \\
\text { Edge alignment }\end{array}$} & Binary iambs & Binary trochees & Ternary iambs \\
\hline & Anti-alignment to R \& L edge & Alignment to $\mathrm{R}$ edge & Anti-alignment to $\mathrm{R}$ edge \\
\hline
\end{tabular}

This table shows two alternative analyses, which I dismiss. Analysis 2 shows a straightforward analysis involving a binary trochee aligned to the right edge of the word, producing forms such as [i.ña.(wé.wa)], whereas analysis 3 involves ternary iambs with anti-alignment to the right edge of the word. Analysis 3 is similar to the analysis adopted here except that it allows for ternary feet involving weakly-layered feet (ternary feet are discussed in Section 3.2). I dismiss these alternative analyses because they are not

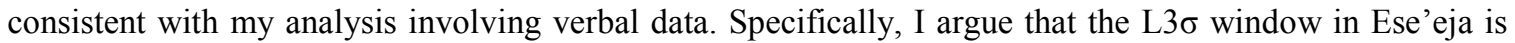
decomposed into left-edge feet and a leftmost constraint which analysis 2 would contradict, and that there is no data which necessarily involve a ternary foot which analysis 3 would contradict.

Furthermore, nouns can be modified by various affixes/clitics. I examine two types of these modifiers: case enclitics $=h o$ LOCATIVE, $=a$ InSTRUMENTAL, and $=a$ ERGATIVE, and the suffix $-m a ́$ PRIVATIVE 'Xless/with no $\mathrm{X} /$ have no $\mathrm{X}$ '. Case clitics assign morphological accent to the final syllable of the stem within an iambic foot. With 1-3 $\sigma$ nouns, morphological accent is assigned to the final syllable of the root, which

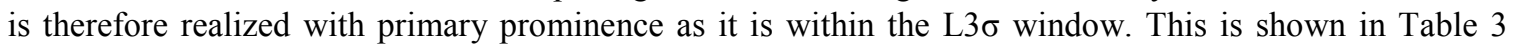
below in rows a., b., and c. [Recall that morphological accent is indicated by underlying the syllable, and surface primary prominence is indicated by boldening and italicizing]. With the 4 syllable noun however, morphological accent is assigned to a position outside the metrical window namely the $4^{\text {th }}$ syllable, shown in row $d$. Here, primary prominence falls on the $2^{\text {nd }}$ syllable of the word, displaying a leftward 'shift'.

Table 3: Accent changes with nouns + case clitics

\begin{tabular}{|c|c|c|c|c|}
\hline & \multicolumn{2}{|r|}{ Isolation } & \multicolumn{2}{|c|}{ Noun + case clitic } \\
\hline a. & $1 \sigma$ & {$[(\boldsymbol{k} \dot{e})]$} & / ké $=$ ho / & [( $(\underline{\boldsymbol{k} e}) \cdot$ ho ] \\
\hline b. & $2 \sigma$ & [ (dá).ki ] & / dakí $=\mathrm{a} /$ & {$[(\overline{\mathrm{da}} \cdot \underline{k i}) \cdot \mathrm{a}]$} \\
\hline c. & $3 \sigma$ & [ (ba.wí).cho ] & / bawichó=a / & [ ba.(wi.chó $). \mathrm{a}]$ \\
\hline d. & $4 \sigma$ & [i.(ña.wé).wa ] & / iñawewá $=a$ / & [ (i.ñá).(we.wà).a ] \\
\hline
\end{tabular}


Under a rhythmic repair analysis, the case clitics assign final morphological accent within a binary iamb. With 3 syllable nouns such as /bawichó=a/, this results in a structure [ba.(wi.chó).a] with a single foot, under the assumption that the grammar generally prohibits degenerate feet. With the 4 syllable noun, accent is assigned to the $4^{\text {th }}$ syllable /iñawewá $=$ a/ which heads a binary iamb. Due to a highly ranked syllableparsing constraint (PARSE-SYL) iterative iambs are formed, [(i.ñá).(we.wá).a]. Primary prominence is assigned to the leftmost foot which we can formalize using a standard LEFTMOST constraint stating that the head foot is the leftmost in the word, surfacing as [(i.ñá).(we.wà).a]. ${ }^{3}$

Further evidence for rhythmic repair is seen when nouns are modified with the privative suffix $-m a ́$, shown in Table 4. This suffix has an inherent accent. This accent aligns with primary prominence when it is one of the first three syllables, as seen with 1 and 2 syllable nouns in rows a. and b. In contrast, with 3 and 4 syllable nouns, primary prominence is on the $2^{\text {nd }}$ and $3^{\text {rd }}$ syllables respectively. If we analyze $-m a ́$ as having an inherent morphological accent and forms an iambic foot, the forms /ke-má/ and /daki-má/ map to [(ke. $\underline{\boldsymbol{m a}})]$ and [da.(ki. $\boldsymbol{m a})$ ], respectively. In contrast, with $3 \sigma$ and $4 \sigma$ nouns the creation of iterative iambs results in additional leftward feet which receive primary prominence due to the LEFTMOST constraint, e.g. /bawicho-má/ and /iñawewa-má/ mapping to [(ba.wí).(cho.mà)] and [i.(ña.wé).(wa.mà)].

Table 4: Accent changes with nouns + privative suffix

\begin{tabular}{|c|c|c|c|}
\hline \multicolumn{2}{|r|}{ Isolation } & \multicolumn{2}{|c|}{ Noun + -ma PRIV } \\
\hline $1 \sigma$ & {$[(\boldsymbol{k e ́})]$} & / ke-má / & {$[(\mathrm{ke} \cdot \boldsymbol{m} \boldsymbol{a} \boldsymbol{a})]$} \\
\hline $2 \sigma$ & [ (dá).ki ] & / daki-má / & [ da.(ki. $\underline{\boldsymbol{m a ́}})$ ] \\
\hline $3 \sigma$ & [ (ba.wí).cho ] & / bawicho-má / & [ (ba.wí).(cho.mà) ] \\
\hline $4 \sigma$ & [ i.(ña.wé).wa ] & / iñawewa-má / & [ i.(ña.wé).(wa.mà) ] \\
\hline
\end{tabular}

In both these cases, there are instances where morphological accent and primary prominence do not align, but where the surface position of prominence is dependent on the position of accent. One should note that other nominal affixes/clitics do not alter the position of accent of the noun, e.g. - $k$ wana PLURAL in $1 \sigma$ [kékwana] 'fields', $2 \sigma$ [péyo-kwana] 'snakes', and $3 \sigma$ [motóne-kwana] 'motors'. These data also show that these affixes/clitics are outside of the domain of accent assignment, e.g. the lack of the form *[ke-kwána].

2.3 Rhythmic effects in the L3 $\sigma$ window with verbs As mentioned above, Ese'eja is a polysynthetic language with at least 64 affixes and clitics which modify verb roots, appearing in at least 14 separate morphological 'slots'. These positions are provided in Table 5 in the theory-neutral verbal template. This table illustrates that inflectional and derivational positions are interleaved.

Table 5: Verbal template - Inflectional slots are shaded

\begin{tabular}{|c|c|c|c|c|c|c|c|c|c|c|c|c|c|c|}
\hline-3 & -2 & -1 & 0 & +1 & +2 & +3 & +4 & +5 & +6 & +7 & +8 & +9 & +10 & +11 \\
\hline 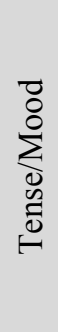 & 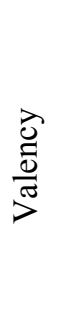 & 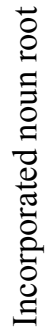 & $\begin{array}{l}1 \\
5 \\
\vdots \\
\vdots \\
0 \\
\vdots \\
0 \\
0\end{array}$ & 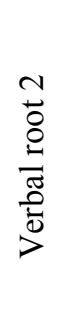 & 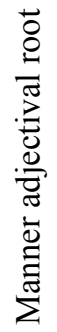 & $\begin{array}{l}\frac{0}{\pi} \\
\frac{\pi}{0} \\
\frac{\dot{0}}{0} \\
\frac{2}{4}\end{array}$ & $\frac{\overrightarrow{0}}{\frac{\overrightarrow{0}}{0}}$ & 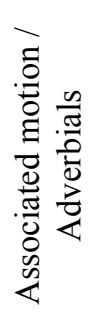 & 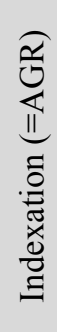 & 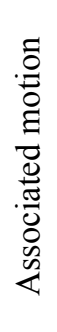 & 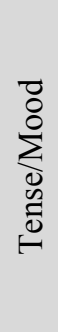 & $\begin{array}{l}\frac{0}{0} \\
\frac{\pi}{0} \\
\frac{0}{0} \\
\frac{2}{2}\end{array}$ & $\begin{array}{l}\overrightarrow{0} \\
\text { 号 } \\
\text { क्य }\end{array}$ & 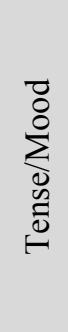 \\
\hline
\end{tabular}

Verb roots in Ese'eja can be classified as transitive or intransitive and are 1-3 syllables in length; ambitransitive roots are limited to only three examples. An example set of verb roots used throughout this

\footnotetext{
${ }^{3}$ Note that I place a grave accent on non-leftmost iambic feet, suggesting that these are realized with secondary prominence (i.e. secondary stress). The issue of secondary stress in Ese'eja is not currently settled, but from present recordings it can optionally surface in a binary rhythm from the primary prominence, as expected.
} 
section is in (3). Note that the $1 \sigma$ root kwya- is phonologically $/ \mathrm{k}^{\mathrm{w}} \mathrm{ja} /, 3 \sigma$ she' $a$ - is phonologically $/ \mathrm{i} \mathrm{fe} \mathrm{ea} /$, and the adjacent identical vowels in $3 \sigma$ root towaa- are heterosyllabic.

(3)

\section{a. Intransitive \\ b. Transitive}

\section{$1 \sigma$}

pa- 'cry'

kwya- 'hit X'
$2 \sigma$

besa- 'bathe'

bana- 'sow X'

\section{$3 \sigma$}

towaa- 'jump'

ishe'a- 'wait for X'

In what follows, I illustrate rhythmic effects involving morphological accent in verb forms with inflectional suffixes only (morphological slots [+6], [+8], and [+11]). Parts of this analysis are found in Vuillermet (2012) and Rolle \& Vuillermet (in press), which I reference when appropriate.

The accent patterns on inflected verbs have been established in these previous publications, and depend on four main variables: the number of syllables, the transitivity of the root, the presence of the $3^{\text {rd }}$ person indexical agreement suffix $-k a$, and the type of tense/mood suffix. Tense/mood suffixes form 4 different accent patterns depending on the position of prominence within their paradigm, which I call suffix accent groups (hereafter SAGs). Like with nouns, verb forms respect the left-edge three syllable window in all cases. The position of prominence cannot be reduced to the syllable count of the word as a whole. Table 6 exemplifies this with intransitive $2 \sigma$ besa- 'bathe' and transitive $2 \sigma$ bana- 'sow X'; full paradigms of verbal accent are provided in Table 15 and Table 16 in the Appendix.

Table 6: Accent patterns on different inflected verb roots

\begin{tabular}{|c|c|c|c|c|}
\hline & $\begin{array}{c}\text { SAG } 1 \\
- \text { me POTENTIAL1 }\end{array}$ & $\begin{array}{c}\text { SAG } 2 \\
\text {-nahe PAST }\end{array}$ & $\begin{array}{c}\text { SAG 3 } \\
\text {-kyae POTENTIAL2 }\end{array}$ & $\begin{array}{c}\text { SAG } 4 \\
\text {-he FUTURE }\end{array}$ \\
\hline Intransitive & $\begin{array}{l}\text { be.sá-me } \\
\text { 'I may bathe' } \\
\text { be.sa-ká:-me } \\
\text { 'They may bathe' }\end{array}$ & $\begin{array}{l}\text { bé.sa-na.he } \\
\text { 'I bathed' } \\
\text { bé.sa-ka-na.he } \\
\text { 'They bathed' }\end{array}$ & $\begin{array}{l}\text { be.sá-kya.e } \\
\text { 'I might bathe' } \\
\text { bé.sa-ka-kya.e } \\
\text { 'They might bathe' }\end{array}$ & $\begin{array}{l}\text { bé.sa-he } \\
\text { 'I will bathe' } \\
\text { be.sá-ka-he } \\
\text { 'They will bathe' }\end{array}$ \\
\hline Transitive & $\begin{array}{l}\text { ba.ná-me } \\
\text { 'I may sow (X)' } \\
\text { ba.na-ká-me } \\
\text { 'He may sow (X)' }\end{array}$ & $\begin{array}{l}\text { ba.ná-na.he } \\
\text { 'I sowed (X)' } \\
\text { bá.na-ka-na.he } \\
\text { 'He sowed (X)' }\end{array}$ & $\begin{array}{l}\text { ba.ná-kya.e } \\
\text { 'I might sow }(\mathrm{X}) \text { ' } \\
\text { bá.na-ka-kya.e } \\
\text { 'He might sow }(\mathrm{X}) \text { ' }\end{array}$ & $\begin{array}{l}\text { ba.ná-he } \\
\text { 'I will sow (X)' } \\
\text { ba.ná-ka-he } \\
\text { 'He will sow (X)' }\end{array}$ \\
\hline
\end{tabular}

One can see that the position of prominence is not consistent within rows and columns nor between them. This suggests morpheme specific morphophonological operations adjusting the position of morphological accent/primary prominence. Vuillermet (2012) examines a large corpus of elicited data involving 75 monomorphemic verb roots and 13 tense/mood inflectional affixes resulting in over 2,000 unique verb forms. This corpus shows robust convergence to the patterns presented here. The categorization of all of these tense/mood suffixes into the various suffix accent groups is provided in Table 17 in the Appendix.

Further, unlike nouns, verb roots are virtually never found in isolation without inflectional morphology and therefore determining the prosodic patterns on non-inflected verbs is not viable. In the few cases where roots are found without inflectional morphology, they typically bare derivational morphology which may alter the position of accent, or undergo what Vuillermet (2012:531) calls 'deaccentuation' when they precede an auxiliary selecting a non-inflected root.

Rolle \& Vuillermet (in press) argue that there are 3 types of morphological accent in the verbal domain: transitive accent, indexical accent, and tense/mood accent. Transitive accent involves assignment of an accent to the final syllable of transitive roots, not found with intransitive roots. This is shown in (4). Transitive accent is indicated with a wavy underline to differentiate it from other morphological accent.

(4) Transitive accent

\section{Intransitive Transitive}
a. $1 \sigma$ pa-
kwyá-
b. $2 \sigma$ besa-
baná-
c. $3 \sigma$ towaa-
ishe’á- 
Additionally, indexical accent is assigned when the third person agreement indexical suffix $-k a$ is present. This involves an assignment of an accent to the first syllable of the stem. Indexical accent overwrites transitive accent and therefore neutralizes the accentual differences between transitive and intransitive roots. It is thereby classified as dominant in the sense of Inkelas (1998). In (5) below, indexical accent is indicated with a double underline.

(5) Indexical accent with suffix $-k a$

\section{Intransitive}

$\begin{array}{lllllll}\text { a. } & 1 \sigma & \text { pa- } & + & -k a & \rightarrow & \text { pá-ka- } \\ \text { b. } & 2 \sigma & \text { besa- } & + & -k a & \rightarrow & \text { bésa-ka- } \\ \text { c. } & 3 \sigma & \text { towaa- } & + & -k a & \rightarrow & \text { tówaa-ka- }\end{array}$

\section{Transitive}

kwyá $+-k a \rightarrow$ kwyá-ka-

baná $+-k a \rightarrow$ bána-ka-

ishe’á $+-k a \rightarrow$ íshe'a-ka-

Finally, tense/mood suffixes involve the assignment of an accent to a position within the stem, forming different suffix accent groups (SAGs). SAGs 1 and 3 assign an accent to the final syllable of the stem, and exclusively consist of suffixes which express mood. SAGs 2 and 4 assign an accent to the penultimate syllable of the stem, and exclusively consist of suffixes which express tense. Table 7 below exemplifies these patterns with intransitive roots. Tense/mood accent is indicated with a dotted under-rinene.

Table 7: Tense/mood accent with intransitive roots

\begin{tabular}{clllllc}
\hline SAG & \multicolumn{1}{c}{$\mathbf{1 \sigma}$} & \multicolumn{1}{c}{$\mathbf{2 \sigma}$} & \multicolumn{1}{c}{$\mathbf{3 \sigma}$} & \multicolumn{2}{c}{ Tense/mood suffix } & Position in stem \\
\hline 1 & páá-me & beśá-me & towaá-me & -me & POT1 & Ultima \\
2 & pá́-nahe & bésa-nahe & towáa-nahe & - -nahe & PST & Penult \\
3 & paá-kyae & beśá-kyae & towaá-kyae & - -kyae & POT2 & Ultima \\
4 & paá-he & bésa-he & towáa-he & -he & FUT & Penult \\
\hline
\end{tabular}

Rolle \& Vuillermet (in press) lay out an additional feature of tense/mood accent assignment, namely the type of behavior which the suffixes display when there is competition between morphological accents. I showed above that indexical accent is dominant, in that it overwrites any other accent present in the stem. In contrast, SAGs 2 and 3 are recessive, meaning that they only assign morphological accent if no accent is already present in the stem. Further, SAGs 1 and 4 are rightmost-preserving, meaning that the rightmost of the two morphological accents wins. This is summarized in Table 8. Due to space, I refer the reader to Rolle \& Vuillermet (in press) for a full account of accent competition and resolution.

Table 8: Morphological accent type

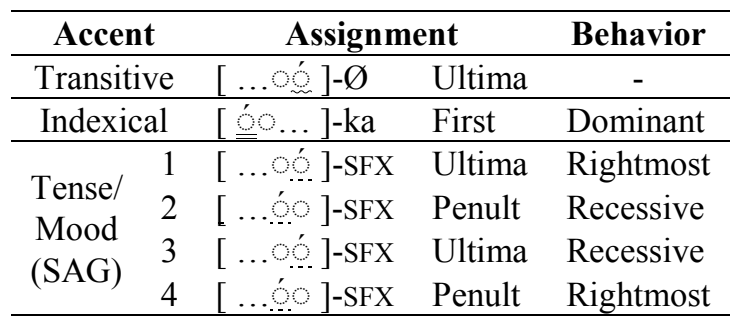

The resolution of the accents competition results in only a single morphological accent present at a later stage in the derivation (for the present purposes, one could assume that to be 'word level phonology'). The 'surviving' morphological accent is exemplified in Table 9 below in column $\mathrm{C}$, designated with a single underline. I illustrate this with intransitive and transitive $3 \sigma$ roots.

As we saw in nouns, iterative footing is enforced based on the position of morphological accent in the word and depending on the particular suffix accent group: SAG 1 enforces iambs, while SAGs 2/3/4 enforce trochees. This is shown in column D. In all of these cases, it is the leftmost foot in the word which receives primary prominence. This is shown in column $\mathrm{E}$, matching the position of primary prominence as documented in the Appendix. 
Table 9: Iterative feet and word level LEFTMOST constraint

\begin{tabular}{|c|c|c|c|c|c|}
\hline $\mathbf{A}$ & B & $\mathbf{C}$ & D & $\mathbf{E}$ & $\mathbf{F}$ \\
\hline SAG & Stem type & Morphological accent & Iterative footing & LEFTMOST & Foot type \\
\hline \multirow{3}{*}{1} & Intr. root & towaá-me & to.(wa.á).me & to.(wa.á).me & \multirow{3}{*}{ Iamb } \\
\hline & Trans. root & ishe'á-me & i.(she.'á).me & i.(she.'á).me & \\
\hline & Root $+-k a$ & ishe'a-ká-me & (i.shé).('a.ká).me & (i.shé).('a.kà).me & \\
\hline \multirow{3}{*}{2} & Intr. root & towáa-nahe & to.(wá.a).(ná.he) & to.(wá.a).(nà.he) & \multirow{3}{*}{ Trochee } \\
\hline & Trans. root & ishe'á-nahe & (í.she).('á.na).he & (í.she).('à.na).he & \\
\hline & Root $+-k a$ & íshe'a-ka-nahe & (1́.she).('á.ka).(ná.he) & (í.she).('à.ka).(nà.he) & \\
\hline \multirow[b]{2}{*}{3} & Intr. root & towaá-kyae & (tó.wa).(á.kya).e & (tó.wa).(à.kya).e & \multirow{2}{*}{ Trochee } \\
\hline & Trans. root & ishe'á-kyae & (í.she).('á.kya).e & (í.she).('à.kya).e & \\
\hline \multirow[b]{2}{*}{4} & Intr. root & towáa-he & to.(wá.a).he & to.(wá.a).he & \multirow[b]{2}{*}{ Trochee } \\
\hline & $\begin{array}{l}\text { Trans. root } \\
\text { Root }+-k a\end{array}$ & $\begin{array}{l}\text { ishe'á-he } \\
\text { ishe’á-ka-he }\end{array}$ & $\begin{array}{l}\text { (í.she).('á.he) } \\
\text { (í.she).('á.ka).he }\end{array}$ & $\begin{array}{l}\text { (í.she).('à.he) } \\
\text { (í.she).('à.ka).he }\end{array}$ & \\
\hline
\end{tabular}

Within this table, I highlight two rhythmic effects. The first is within SAG 1 where the relevant cells have a solid border line and dark shading. In this case, the output to morphological accent resolution is /ishe'a-ká$\mathrm{me} /$ with accent on the $4^{\text {th }}$ syllable, outside the metrical window. This adheres to constraints enforcing iambic iterative footing and leftmost prominence, and consequently primary prominence falls on the $2^{\text {nd }} \sigma$. A second rhythmic effect is within SAGs $2 / 3 / 4$ where the relevant cells have a dotted border line and light shading. In these cases, the output has accent on the $3^{\text {rd }}$ syllable, e.g. /ishe'á-he/ in SAG 4. In these cases, because these forms adhere to constraints enforcing trochaic footing as well as the leftmost constraint, primary prominence falls on the $1^{\text {st }}$ syllable of the word, even though the morphological accent is one of the first three syllables of the word (i.e. within the L3 $\sigma$ ). Both of these rhythmic effects show primary prominence surfacing on a position rhythmically dependent on morphological accent.

One typologically rare component to this analysis is positing morphologically conditioned iambs vs. trochees, making Ese'eja what Goedemans \& van der Hulst (2013) refer to as a 'dual rhythm' language. Rolle \& Vuillermet (in press) capture this through cophonologies (Inkelas \& Zoll 2007), in which SAG 1 affixes trigger the formation of iambs through a cophonology ranking RHTYPE $=\mathrm{I}>>$ RHTYPE $=\mathrm{T}$, while SAGs $2 / 3 / 4$ affixes trigger trochees through an opposite ranking RHTYPE $=\mathrm{T}>>$ RHTYPE $=\mathrm{I}$. Although morphological conditioning of dual rhythm is exceptional (if not unique), cross-linguistic research has revealed countless ways in which prosody can be morphologically conditioned (see Inkelas 2014 for an overview). Thus, while it may hold that rhythm is 'post-grammatical' and insensitive to morphological/morphosyntactic information in the sense that "words cannot be marked as exceptions to rhythm or as subject to a special form of rhythm' (van der Hulst 2012:1497), Ese'eja illustrates that the iambic/trochaic 'setting' can indeed be sensitive to such information. ${ }^{4}$

\section{Discussion}

3.1 Against a 'default repair' alternative One alternative to this paper's analysis is that the Ese'eja accent paradigms are the result of morphological accent in conjunction with three morphosyntactically conditioned defaults. I call this the default repair alternative, illustrated in Table 10.

\footnotetext{
${ }^{4}$ Dual rhythm languages have been noted in areally proximate Panoan languages, as well (Bennett 2013, Tallman 2014:505, González 2016). Further, impressionistically there are no apparent differences between the phonetic cues of primary prominence (pitch, length, intensity, vowel quality) in iambs vs. trochees. Instrumental analysis is required to further support Ese'eja as a 'dual rhythm' language.
} 
Table 10: Three defaults under default repair alternative (Argued against)

\begin{tabular}{|c|c|c|c|c|c|}
\hline $\begin{array}{l}\text { Default } \\
\text { type }\end{array}$ & $\begin{array}{l}\text { Morphosyntactic } \\
\text { condition }\end{array}$ & $\begin{array}{l}\text { Morphological } \\
\text { accent }\end{array}$ & $\begin{array}{l}\text { Metrical } \\
\text { window }\end{array}$ & $\begin{array}{l}\text { Primary } \\
\text { prominence }\end{array}$ & $\begin{array}{l}\text { Position of } \\
\text { default }\end{array}$ \\
\hline Default 1 & $\begin{array}{l}\text { SAG } 1 \\
\text { Case clitics }\end{array}$ & $\begin{array}{l}/ \text { ishe'a-ká-me / } \\
/ \text { iñawe:wá=a / }\end{array}$ & $\mathrm{L} 3 \sigma$ & $\begin{array}{l}\text { [ (i.shé).'a.ka.me ] } \\
\text { [ (i.ñá).we.wa.a ] }\end{array}$ & \\
\hline Default 2 & SAGs $2 / 3 / 4$ & / ishe'á-nahe / & $\mathrm{L} 2 \sigma$ & [ (í. she).'a.na.he ] & $1^{\mathrm{st}} \sigma$ \\
\hline Default 3 & Noun in isolation & / iñawe wa / & $\mathrm{L} 3 \sigma$ & [i.(ña.wé).wa ] & $3^{\text {rd }} \sigma$ \\
\hline
\end{tabular}

Default 1 would be conditioned by SAG 1 suffixes on verbs and case clitics on nouns. In this type, when morphological accent falls outside the left-edge 3 syllable window, primary prominence is assigned to the $2^{\text {nd }}$ syllable of the word. Second position can therefore be understood as the default position for prominence. In contrast, default 2 would be conditioned by SAGs $2 / 3 / 4$ and assign prominence to the initial syllable of the word by default. Crucially, this default must co-occur with a left-edge 2 syllable window rather than a 3 syllable one, otherwise we would expect forms such as /ishe'á-nahe/ to show alignment between accent and prominence, resulting in unattested surface forms such as *[i.she.'á.na.he]. Finally, default 3 would apply to nouns in isolation, and show default stress on the $3^{\text {rd }}$ syllable (though note that there is only one monomorphemic $4 \sigma$ noun). Although abstract, positing multiple defaults to account for surface stress patterns when morphological accent falls outside a metrical window has precedence in the literature. Caballero (2011) argues for two defaults in Choguita Rarámuri, a $2^{\text {nd }}$ position default and a $3^{\text {rd }}$ position default depending on morphological context, modeled using cophonologies.

I reject this alternative default repair based on two arguments. One argument is that this alternative makes no explicit link between the position of window-external morphological accent and the position of primary prominence. As shown in Table 10, SAG 1 affixes and case clitics place an accent on the $4^{\text {th }}$ syllable and have default on the $2^{\text {nd }}$ syllable, whereas SAG 2/3/4 affixes place an accent on the $3^{\text {rd }}$ syllable but have default on the $1^{\text {st }}$ syllable. Under the alternative, there is no principled reason why these affixes should trigger these defaults, and their rhythmic relationship would stand as a coincidence. In contrast, this paper's rhythmic analysis does provide a principled reason for the position of primary prominence.

A second argument is that this alternative does not account for the position of primary prominence with the privative suffix $-m a ́$ without a major stipulation. Recall from Table 4 that $-m a ́$ has an inherent accent which surfaces with primary prominence with $1 \sigma$ and $2 \sigma$ nouns. When - $m a$ falls outside the metrical window, with $3 \sigma$ nouns prominence falls on the $2^{\text {nd }}$ syllable whereas with $4 \sigma$ nouns it falls on the $3^{\text {rd }}$ syllable. This is schematized below in Table 11. Under default repair, we would again have to assume multiple default cophonologies, but unlike with the morphological triggers detailed above in Table 10, the suffix - má would not be associated with a single cophonology. When appearing with a $3 \sigma$ root, default would fall on the $2^{\text {nd }}$ syllable, but with a $4 \sigma$ root, default would be on the $3^{\text {rd }}$. Even under the assumption that one could account for this through cophonologies (e.g. through phonologically conditioned allomorphy of -má whose allomorphs trigger distinct defaults), this again would view the rhythmic relationship between morphological accent and its default as a coincidence, and offer no principled reason otherwise.

Table 11: Multiple defaults with suffix - má (Argued against)

\begin{tabular}{|c|c|c|c|c|c|c|}
\hline \multicolumn{6}{|c|}{ Noun + -ma PRIV } & Default \\
\hline $1 \sigma$ & /ke-má/ & (ke.má) & $3 \sigma$ & /bawicho-má/ & (ba.wí).cho.ma & $2^{\text {nd }} \sigma$ \\
\hline $2 \sigma$ & /daki-má/ & da.(ki.má) & $4 \sigma$ & /iñawewa-má/ & i.(ña.wé).wa.ma & $3^{\text {rd }} \sigma$ \\
\hline
\end{tabular}

3.2 Formalizing rhythmic vs. default repair This analysis of Ese'eja has posited a novel form a 'repair' when morphological accent is assigned outside of a metrical window. One important aspect which therefore needs to be addressed is how to formalize rhythmic repair within Generative Grammar, and in particular Optimality Theory. I sketch a formal analysis parametrizing the difference between default and rhythmic repair using distinct constraint orders, though limit this discussion due to space.

Kager (2012) analyzes metrical windows as being epiphenomenal in the sense that they can be decomposed into a number of common OT constraints which are needed independently to account for prosodic systems without metrical windows. I call this the 'decomposable' view of windows. Kager 
contrasts this to analyses of metrical windows as phonological domains and/or objects (Kager 2012:1454), which I call the 'non-decomposable' view. Like Kager, my analysis follows the decomposable view.

Kager presents a series of arguments in favor of decomposing metrical windows into weakly layered ternary feet interacting with word edge alignment constraints. Weakly layered ternary feet are split into two components with up to three syllables total: the 'head' which is denoted in square brackets, and the 'adjunct', which is a syllable contained within the foot but not within the head. Depending on a grammar's constraint ranking, the adjunct may appear before the foot, after the foot, or not be allowed at all in which case there are strictly binary feet (Gen allows only one adjunct). A set of examples are in Table 12.

Table 12: Some potential shapes of weakly-layered feet (Kager 2012:1482)

\begin{tabular}{lcccc}
\hline & head + adjunct & adjunct + head & no adjunct & adjunct + head + adjunct \\
\hline binary head, trochee & $\left(\left[\sigma^{\prime} \sigma\right] \sigma\right)$ & $\left(\sigma\left[\sigma^{\prime} \sigma\right]\right)$ & $\left(\left[\sigma^{\prime} \sigma\right]\right)$ & $*\left(\sigma\left[\sigma \sigma^{\prime}\right] \sigma\right)$ - not possible \\
binary head, iamb & $\left(\left[\sigma \sigma^{\prime}\right] \sigma\right)$ & $\left(\sigma\left[\sigma \sigma^{\prime}\right]\right)$ & $\left(\left[\sigma \sigma^{\prime}\right]\right)$ & $*\left(\sigma\left[\sigma \sigma^{\prime}\right] \sigma\right)-$ not possible \\
\hline
\end{tabular}

Metrical windows emerge when a ternary (or binary) foot must appear at a domain edge due to a highlyranked edge-alignment constraint. If a designated accent such as morphological accent falls on a syllable at this domain edge, it can be realized with primary prominence because it would not violate the edgealignment constraint. If, however, it is too far away from the edge, it is not realized with prominence and instead lower ranked constraints result in primary prominence falling on a default position. The general logic of default repair therefore is word-to-foot alignment constraints ranked above (1) a FAITH-ACCENT constraint mapping accent to surface prominence, (2) a PARSE-SYL constraint enforcing parsing syllables, and (3) foot type constraints dictating the default foot type resulting in default stress.

(6) Default repair - general logic involving OT constraints

Word-to-foot alignment $>>\{$ FAITH-ACCENT $\sim$ PARSE-SYL $\sim$ Foot type constraints $\}$

This is shown in a toy example in Table 13 (based on Kager 2012:1484). Here, an input with morphological accent on the fourth syllable / $\sigma \sigma \sigma \sigma \sigma \sigma /$ is evaluated with constraints enforcing a left-edge $3 \sigma$ window. Candidate e. shows alignment between morphological accent and surface prominence satisfying FAITH-ACCENT, but is eliminated due to the highly ranked word-to-foot alignment constraint ALIGN-WD-L, which states that every word aligns a foot to its left edge (i.e. every word begins with a foot) (Kager 1999:169). Constraints determining foot type PARSE-SYL, HD-IAMB, and ALIGN-HD-R eliminate the other candidates, resulting in candidate $\mathrm{d}$. winning with default stress on the $3^{\text {rd }} \sigma$ (a default ternary iamb).

Table 13: Constraint ranking example showing default repair

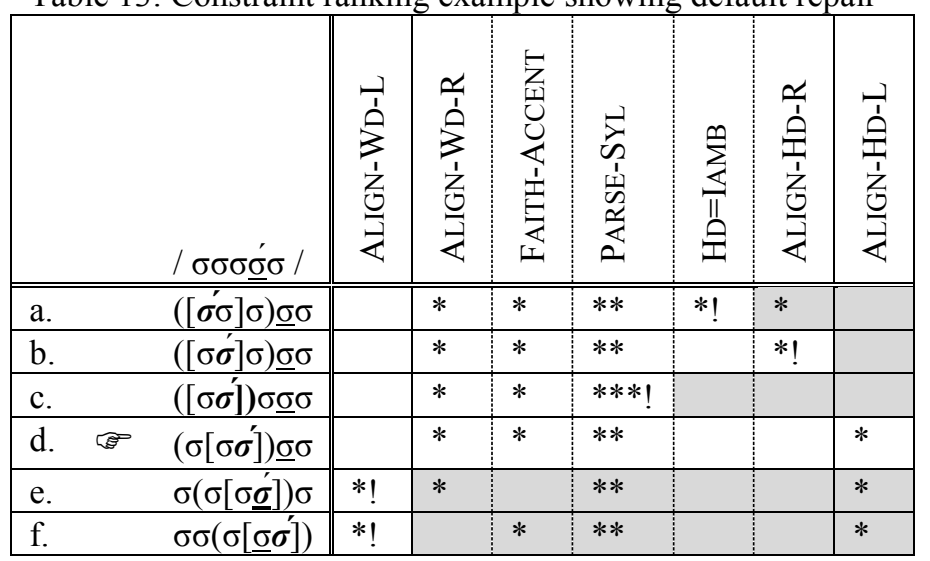

Throughout Kager's analysis of metrical windows, he does not take into account words with multiple feet (e.g. iterative footing) or rhythm, and states explicitly that his theory and typology are 'ignoring secondary prominences' (Kager 2012:1455). However, he does utilize the PARSE-SYL constraint in order to derive 
ternary feet. Given the assumptions of factorial typology, we predict to find prosodic systems with these constraints in a different ranking. I argue that Ese'eja rhythmic repair confirms this prediction.

I derive rhythmic patterns like the Ese'eja data with the toy example repeated in Table 14 below. Here, ALIGN-HD constraints are ranked very high which enforce the alignment of the head of the foot to both edges of the foot and have the effect of allowing only binary feet, eliminating candidates a.-j. In the next crucially ranked area, PARSE-SYL is highly ranked and enforces iterative feet eliminating k.-1., LEFTMOST selects the leftmost foot in the word as bearing primary prominence eliminating q.-r., and *FOOTLAPSE prohibits feet from being separated by unfooted syllables eliminating o. $([\dot{\sigma} \sigma]) \sigma([\underline{\sigma} \sigma])$.

Further, the tableau in Table 13 above involved a constraint FAITH-ACCENT, which Kager defines as follows: 'a lexical accent should be realized as primary stress'. I split this into two constraints: ACCENT-TOPRIMARYPROMINENCE (ACC-PRIMPROM), which states that accent is realized with primary prominence, versus ACCENT-TO-PROMINENCE (ACC-PROM), which states accent is realized with prominence generally but not necessarily primary. If we rank ACC-PROM over ACC-PRIMPROM, the surviving candidates are only m. $\sigma\left(\left[\tilde{\sigma}^{\prime} \sigma\right]\right)([\underline{\sigma} \sigma])$ and n. $\sigma([\sigma \sigma])([\underline{\sigma} \sigma])$. Subsequently, candidate n. is eliminated by ranking $\mathrm{HD}=\mathrm{TROCH} \gg>$ $\mathrm{HD}=\mathrm{IAMB}$, which enforce trochees and iambs respectively (equivalent to RHTYPE $=\mathrm{T}$ and RHTYPE $=\mathrm{I}){ }^{5}$

Table 14: Constraint ranking example showing rhythmic repair

\begin{tabular}{|c|c|c|c|c|c|c|c|c|c|c|c|c|}
\hline & / $\sigma \sigma \sigma \underline{\sigma \sigma}$ / & 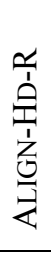 & 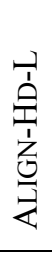 & 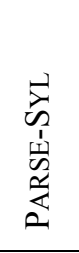 & 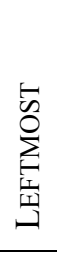 & 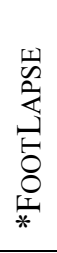 & 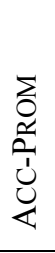 & 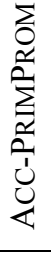 & 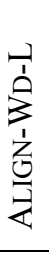 & 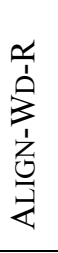 & 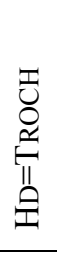 & 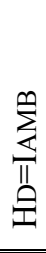 \\
\hline a. & $([\dot{\sigma} \sigma] \sigma) \underline{\sigma} \sigma$ & $* !$ & & $* *$ & & & $*$ & $*$ & & $*$ & & $*$ \\
\hline b. & $([\sigma \sigma] \sigma) \underline{\sigma} \sigma$ & $* !$ & & $* *$ & & & $*$ & $*$ & & $*$ & $*$ & \\
\hline c. & $\left(\sigma\left[\sigma \boldsymbol{\sigma}^{\prime}\right]\right) \underline{\sigma} \sigma$ & & $* !$ & $* *$ & & & * & $*$ & & $*$ & $*$ & \\
\hline $\mathrm{d}$. & $\sigma(\sigma[\sigma \underline{\boldsymbol{\sigma}}]) \sigma$ & & $* !$ & $* *$ & & & & & $*$ & $*$ & $*$ & \\
\hline e. & $\sigma \sigma\left(\sigma\left[\underline{\sigma} \sigma \sigma^{\prime}\right)\right.$ & & $* !$ & $* *$ & & & $*$ & $*$ & $*$ & & $*$ & \\
\hline f. & $\sigma([\dot{\sigma} \sigma] \underline{\sigma}) \sigma$ & $* !$ & & $* *$ & & & * & $*$ & * & $*$ & & $*$ \\
\hline g. & $\sigma \sigma([\sigma \underline{\sigma}] \sigma)$ & $* !$ & & $* *$ & & & & & $*$ & & $*$ & \\
\hline h. & $\left(\left[\sigma^{\prime} \sigma\right] \sigma\right)([\underline{\sigma} \sigma])$ & $* !$ & & & & & & $*$ & & & & $* *$ \\
\hline i. & $(\sigma[\dot{\sigma} \sigma])([\underline{\sigma} \sigma])$ & & $* !$ & & & & & $*$ & & & & $* *$ \\
\hline j. & $\left(\left[\tilde{\sigma}^{\prime} \sigma\right]\right)(\sigma[\underline{\sigma} \sigma])$ & & $* !$ & & & & & $*$ & & & & $* *$ \\
\hline $\mathrm{k}$. & $\sigma \sigma([\sigma \underline{\sigma}]) \sigma$ & & & $* * ! *$ & & & & & $*$ & $*$ & $*$ & \\
\hline 1. & $([\sigma \sigma]) \sigma \underline{\sigma} \sigma$ & & & $* * ! *$ & & & * & $*$ & & $*$ & $*$ & \\
\hline $\mathrm{m}$. & $\sigma\left(\left[\tilde{\sigma}^{\prime} \sigma\right]\right)([\underline{\sigma} \sigma])$ & & & $*$ & & & & $*$ & $*$ & & & $* *$ \\
\hline n. & $\sigma([\sigma \tilde{\sigma}])([\underline{\sigma} \sigma])$ & & & $*$ & & & & $*$ & $*$ & & $* !$ & $*$ \\
\hline o. & $([\dot{\sigma} \sigma]) \sigma([\underline{\sigma} \sigma])$ & & & $*$ & & $* !$ & & $*$ & & & & $* *$ \\
\hline p. & $\left(\left[\tilde{\sigma}^{\prime} \sigma\right]\right)([\dot{\sigma} \underline{\sigma}]) \sigma$ & & & $*$ & & & $* !$ & $*$ & & $*$ & & $* *$ \\
\hline q. & $\sigma([\dot{\sigma} \sigma])([\underline{\sigma} \sigma])$ & & & $*$ & $* !$ & & & & $*$ & & & $* *$ \\
\hline r. & $([\dot{\sigma} \sigma])\left(\left[\sigma^{\prime} \underline{\sigma}\right]\right) \sigma$ & & & $*$ & $* !$ & & $*$ & & & $*$ & & $* *$ \\
\hline
\end{tabular}

Crucially, the alignment constraints ALIGN-WD-L and ALIGN-WD-R are low and do not serve to eliminate active candidates (cf. default repair in Table 13 where they are highly ranked). The general logic then of

\footnotetext{
${ }^{5}$ One may posit that the creation of an iamb versus a trochee under distinct cophonologies occurs only at the derivational level when the tense/mood suffixes are introduced. Candidate $\mathrm{m}$. would therefore be selected due to not violating * CLASH prohibiting surface adjacent prominences.
} 
rhythmic repair is highly ranked PARSE-SYL, an EDGEMOST constraint, and ACCENT-TO-PROMINENCE, followed by lower ranked ACCENT-TO-PRIMARYPROMINENCE and word-to-foot alignment constraints.

(7) Rhythmic repair - general logic involving OT constraints

$\{$ PARSE-SYL $\sim$ EDGEMOST $\sim$ ACC-PROM $\}>>$ ACC-PRIMPROM $\sim$ Word-to-foot alignment $\}$

My analysis utilizes weakly-layered feet constraints ALIGN-HD-L and ALIGN-HD-R and ranks them highly to enforce strict binary feet and rule out the ternary feet in candidates a.-j. in Table 14. However, assuming ternary feet is not a necessary component of this analysis. One could assume that ternary feet are not allowed by Gen and therefore there would be no need to eliminate them. I do not wish to argue that ternary feet are unnecessary constructs cross-linguistically given Kager's (2012) arguments against accounting for $3 \sigma$ metrical windows via alternatives such as extrametricality or anti-lapse constraints. However, if this analysis of Ese'eja is correct, it presents an instance of a L $3 \sigma$ window which does not require ternary feet, a pattern not found in Kager's typology.

\section{Conclusion}

The main claim of this paper was that Ese'eja provided empirical support for rhythmic repair, a novel type of repair seen when phonological accents falls on a position outside of a metrical window. I demonstrated that although the position and behavior of the morphological accent depends on the specific morphological sponsor, there is evidence for rhythmic repair and rhythmic effects in all cases. I provided two arguments against the default repair alternative, and formalized the differences between default repair and rhythmic repair involving the relative ranking of PARSE-SYL, EDGEMOST constraints, word-to-foot alignment constraints, and constraints ACCENT-TO-PROMINENCE and ACCENT-TO-PRIMARYPROMINENCE.

\section{Appendix}

Table 15: Location of primary prominence with intransitive roots -4 distinct suffix accent groups (SAGs)

\begin{tabular}{|c|c|c|c|c|}
\hline Intransitive & $\begin{array}{c}\text { SAG 1 } \\
\text {-me POT1 } \\
\end{array}$ & $\begin{array}{c}\text { SAG } 2 \\
\text {-nahe PST } \\
\end{array}$ & $\begin{array}{c}\text { SAG } 3 \\
-\mathrm{kyae} \text { РОТ2 }\end{array}$ & $\begin{array}{l}\text { SAG } 4 \\
\text {-he FUT }\end{array}$ \\
\hline $1 \sigma$ & $\begin{array}{l}\text { pá-me } \\
\text { pa-ká-me }\end{array}$ & $\begin{array}{l}p a ́ \text {-na.he } \\
p a ́ \text {-ka-na.he }\end{array}$ & $\begin{array}{l}\text { pá-kya.e } \\
\text { pá-ka-kya.e }\end{array}$ & $\begin{array}{l}\text { pá-he } \\
\text { pá-ka-he }\end{array}$ \\
\hline $2 \sigma$ & $\begin{array}{l}\text { be.sá-me } \\
\text { be.sa-ká-me }\end{array}$ & $\begin{array}{l}\text { bé.sa-na.he } \\
\text { bé.sa-ka-na.he }\end{array}$ & $\begin{array}{l}\text { be.sá-kya.e } \\
\text { bé.sa-ka-kya.e }\end{array}$ & $\begin{array}{l}\text { bé.sa-he } \\
\text { be.sá-ka-he }\end{array}$ \\
\hline $3 \sigma$ & $\begin{array}{l}\text { to.wa.á-me } \\
\text { to.wá.a-ka-me }\end{array}$ & $\begin{array}{l}\text { to.wá.a-na.he } \\
\text { tó.wa.a-ka-na.he }\end{array}$ & $\begin{array}{l}\text { tó.wa.a-kya.e } \\
\text { tó.wa.a-ka-kya.e }\end{array}$ & $\begin{array}{l}\text { to.wá.a-he } \\
\text { tó.wa.a-ka-he }\end{array}$ \\
\hline
\end{tabular}

Table 16: Location of primary prominence with transitive roots -4 distinct suffix accent groups (SAGs)

\begin{tabular}{|c|c|c|c|c|}
\hline Transitive & $\begin{array}{c}\text { SAG } 1 \\
- \text { me РOT1 }\end{array}$ & $\begin{array}{c}\text { SAG 2 } \\
\text {-nahe PST }\end{array}$ & $\begin{array}{c}\text { SAG } 3 \\
- \text { kyae РОт2 }\end{array}$ & $\begin{array}{l}\text { SAG } 4 \\
\text {-he FUT }\end{array}$ \\
\hline $1 \sigma$ & $\begin{array}{l}\boldsymbol{k} \boldsymbol{w y} \boldsymbol{a} \text {-me } \\
\text { kwya-ká-me }\end{array}$ & $\begin{array}{l}\boldsymbol{k} \boldsymbol{w} \boldsymbol{y} \boldsymbol{a} \text {-na.he } \\
\boldsymbol{k} \boldsymbol{w} \boldsymbol{y} \boldsymbol{a}-\mathrm{ka}-\mathrm{na} \text { he }\end{array}$ & $\begin{array}{l}\text { kwyá-kya.e } \\
\text { kwyá-ka.kya.e }\end{array}$ & $\begin{array}{l}\text { kwyá-he } \\
\boldsymbol{k} \boldsymbol{w} \boldsymbol{y} \boldsymbol{a} \text {-ka-he }\end{array}$ \\
\hline $2 \sigma$ & $\begin{array}{l}\text { ba.ná-me } \\
\text { ba.na-ká-me }\end{array}$ & $\begin{array}{l}\text { ba.ná-na.he } \\
\text { bá.na-ka-na.he }\end{array}$ & $\begin{array}{l}\text { ba.ná-kya.e } \\
\text { bá.na-ka-kya.e }\end{array}$ & $\begin{array}{l}\text { ba.ná-he } \\
\text { ba.ná-ka-he }\end{array}$ \\
\hline $3 \sigma$ & $\begin{array}{l}\text { i.she.'á-me } \\
\text { i.shé.'a-ka-me }\end{array}$ & $\begin{array}{l}\text { í.she.'a-na.he } \\
\text { í.she.'a-ka-na.he }\end{array}$ & $\begin{array}{l}\text { í.she.'a-kya.e } \\
\text { í.she.'a-ka-kya.e }\end{array}$ & $\begin{array}{l}\text { í.she.'a-he } \\
\text { í.she.'a-ka-he }\end{array}$ \\
\hline
\end{tabular}


Table 17: List of tense/mood suffixes and which suffix accent group (SAG) they belong to

\begin{tabular}{|c|c|c|c|c|}
\hline Category & Subcategory & Morpheme(s) & Morphological slot(s) & SAG \\
\hline \multirow{7}{*}{ Tense } & PRESENT & -ani $\sim$ aña & +11 & 4 \\
\hline & PRESENT & $-(\mathrm{e}) \mathrm{ki}$ & +11 & 4 \\
\hline & PRESENT & -haa & +11 & 4 \\
\hline & PRESENT & -ba'e & +11 & 4 \\
\hline & FUTURE & -he & +8 & 4 \\
\hline & REMOTE PAST & -a =pwá & +11 (+clitic) & - \\
\hline & PAST & -(a)nahe & +11 & 2 \\
\hline \multirow{6}{*}{$\begin{array}{c}\text { Mood/ } \\
\text { Commands }\end{array}$} & POTENTIAL 2 & -kyae & +11 & 3 \\
\hline & Potential 1 & - me & +11 & 1 \\
\hline & EXTERNAL OBLIGATION & $-\mathrm{ka} \ldots-. \mathrm{ji}$ & $+6 \ldots+11$ & 1 \\
\hline & IMPERATIVE & -kwe & +11 & 1 \\
\hline & PROHIBITIVE & a'a ...-ji & $($ particle $) \ldots+11$ & 1 \\
\hline & APPREHENSIVE & -chana & +11 & 1 \\
\hline
\end{tabular}

\section{References}

Alderete, John. 2001. Morphologically governed accent in Optimality Theory. New York: Routledge.

Bennett, Ryan. 2013. The uniqueness of metrical structure: Rhythmic phonotactics in Huariapano. Phonology 30:355398.

Caballero, Gabriela. 2011. Morphologically conditioned stress assignment in Choguita Rarámuri (Tarahumara). Linguistics 49(4):749-790.

Goedemans, Rob \& Harry van der Hulst. 2013. Rhythm types. In Matthew S. Dryer \& Martin Haspelmath (eds.), The world atlas of language structures online.

González, Carolina. 2016. Tipología de los sistemas métricos de veinticinco lenguas pano. Amerindia 39(1):129-172.

Hulst, Harry van der. 2012. Deconstructing stress. Lingua 122:1494-1521.

Inkelas, Sharon. 1998. The theoretical status of morphologically conditioned phonology: A case study from dominance. In Geert Booij \& Jaap van Marle (eds.), Yearbook of morphology 1997. Dordrecht: Springer Netherlands. 121155.

Inkelas, Sharon. 2014. The interplay of morphology and phonology. Oxford: Oxford University Press.

Inkelas, Sharon \& Cheryl Zoll. 2007. Is grammar dependence real? A comparison between cophonological and indexed constraint approaches to morphologically conditioned phonology. Linguistics 45(1):133-171.

Kager, René. 1999. Optimality Theory. Cambridge: Cambridge University Press.

Kager, René. 2012. Stress in windows: Language typology and factorial typology. Lingua 122:1454-1493.

Key, Mary R. \& Richard Wyma. 1964. Analyzing stress in Chama (Tacanan). Chapman College Research Bulletin $1(1): 28-37$.

Rolle, Nicholas \& Marine Vuillermet. In press. Morphologically assigned accent and an initial three syllable window in Ese'eja. In Rob Goedemans, Harry van der Hulst \& Jeffrey Heinz (eds.), The study of word stress and accent: Theories, methods and data. Cambridge: Cambridge University Press.

Rolle, Nicholas. 2013. Ese Ejja Accent. UC Berkeley Phonology Lab Annual Report (2013). 268-280.

Tallman, Adam. 2014. The prosody of split and glued verb constructions in Chácobo (Pano). Proceedings of the Berkeley Linguistic Society 40:495-522.

Vuillermet, Marine. 2012. A Grammar of Ese Ejja. Dissertation, Université Lumière Lyon 2. 